\title{
A Contribution made by Shokan Ualikhanov to the History of Middle Ages in Central Asia
}

\author{
Aurika Temirkhanovna Serubaeva, Arna Saparkalievna Sarsambekova \\ L.N. Gumilyov Eurasian National University, Doctorant of the Department of Eurasian research \\ Republic of Kazakhstan, 010000, Astana, Mirsoyan Street, 2 \\ L.N. Gumilyov Eurasian National University, Associate professor of the Department of Eurasian research \\ Republic of Kazakhstan, 010000, Astana, Mirsoyan Street, 2
}

\section{ABSTRACT}

Shokan Ualikhanov is a scientist who made a huge contribution to the history of Central Asia. Shokan's works were not only known worldwide while he was alive but also were of great value to science these days. He was not only noticed by virtue of his special talent, knowledge, good observance and high intelligent skills and being an orientalist hopeful about the future among the highly-qualified Russian scientists but also on top of that he was the first Kazakh scientist who left a considerable mark on European science and culture. Followed by the outstanding Marko Polo, Shokan Ualikhanov's travel to Kashgar was the first brave deed by giving a many-sided discription of blind spots in Cetral Asia and introducing them to Europe. In this research Shokan Ualikhanov's contibution to the study of the history of Middle Ages in Cetral Asia was realized, his works in this field were analized.

\section{Indexing terms/Keywords}

Cetral Asia, the Middle Ages, orientalist, Kashgar, Zhongar, genealogy, legend «Manas», Ancient East, East Turkestan, Islam in steppe, shamanism.

\section{Academic Discipline And Sub- Disciplines}

History of Central Asia

\section{Subject Classification}

The role of personality

\section{Type (METHOT/APPROACH)}

The research was carried out by comparing historic, many-sided analisis and combination, order and other scientific tutorial approaches on top. A great attention was paid to the worldwide developing science of biography. A scientic heritage of a person was analyzed, his contribution to science and art, while investigating, the development of the whole civilization was taken into consideration.

Sh. Ualihanov widely put into practice different kinds of research methods, which are necessary now days too. For instance, Louis Cohen, Lawrence Manion, Keith Morrison, Historical research employs a number of methods and makes use of a wide range of source materials. These include oral sources in relation to the recent past, based on interviews in which respondents recall their own experiences as historical evidence. Nevertheless, analysis of documents has been the most characteristic and traditional method employed in modern historical research as distinct from social research. The established practices of working historians are therefore a key point of departure in addressing documentary research, although historians have tended not to reflect in detail or depth on this central aspect of their craft [1].

Also, you can not to write and to analyze information without the participant observation. As Harvey Russell Bernard said, more and more researches these days, across the social sciences, have learned what a powerful method powerful participant observation is it all stages of the research process. The method stands on its own, but it is also increasingly part of a mixed-method strategy, as researches combine qualitative data to answer questions of interest.

The ethnography produced ideas for policy recommendations and for the content for the questionnaire. The questionnaire data illuminated and validated many of the things that the ethnographer learned during participant observation [2].

Shokan Ualikhanov was the first who established in the scientific circle a new type of historic data, oral folk traditions of Kazakh and Kirgiz people. Our research was mainly based on the works of Shokan Ualikhanov. Especially, Shokan Ualikhanov's works in the history of Central Asia were widely used in the research. These are: "Zhongar features», the legend «Manas», Sh. Ualikhanov's «Khan's orders» reviewed by Berezin I.N., «The remains of shamanism in Kazakhstan», "Kazakh genealogy», "Six spheres or Chinese province Nan-Lu (Small Bukhariya) about the life in six eastern towns between 1858 and 1859 ». Certainly, Shokan left works connected with the present time and we only worked by analyzing his works.

\section{Council for Innovative Research}

Peer Review Research Publishing System

Journal of Social Science Research

Vol.4, No.1 


\section{INTRODUCTION}

Despite the fact that Cetral Asia was located between the two great countries for many years, for Europe it was a mystery. "Central Asia hasn't been explored more than inner Africa» once said Semenov P.P. about it. "In fact, false and controversial data given in our geographical glossaries about Central Asia, this land, like in old times, is not even a developed terra incognita but at least it is like a pictorial puzzle which makes us think and we don't know anything about people in Central Asia» [3, p. 341] Shokan Ualikhanov wrote. Clearly seen in the words by Semenov P.P. and Shokan Ualikhanov, it was another study of that time in the ttimeless scientific research of Central Asia.

One of the west scientists, professor Alan Bryman said about Central Asia: «... the provinces along the Jaxartes, from Farghanah, to Shash, modern Tashkand, with the Isbijub province to the north-west, beyond which the Jaxartes flowed out, through the bleak wilderness, into the upper-part of the Aral sea. Of these northern countries of the Further East, however lying beyond Central Asia, the early Arab geographers give but succinct account. There were the Turk lands, and it was only after the Mongol invasion that they rose to importance; of this period unfortunately there is a lack of precise information, the Arab geographers failing us for the most part, and they place being but ill-supplied by the later Persian and Turkish authorities» [4].

Shokan Ualikhanov in his work «Features of Zhongar» by researching Central Asia feels sorry for its lack in culture and prosperity, its life in dark. "Ancient East (XVI and XV centuries) on the one hand was very wealthy and rich and on the other hand Maurenakhr now was very unlearned and poor. The libraries in Samarkand, Tashkent, Fergana, Khiya, Bukhara, etc, the observatory in in Samarkand everything except religious education cursed by the Tatars and due to vandalism and foreign inquisition were completely destroyed» Shokan wrote [3, pp. 341-342]. The members of mosques destroyed all ancient artifacts and only madrasahs, mosques, graves for Muslim holy men were left.

In addition, Shokan Ualikhanov was worried about the leaders in Central Asia who didn't write any songs, notes as their ancestors had done before, were far from science and knowledge, focused more on the religion. Shokan, if we take into consideration Small Bukhariya, the situation was not satisfying: «Despite Islam's dominance, women's freedom, religious passion, people's disobedience and municipal beginnings of a developed country, first of all, now became poor from Chinese officials and military leaders... Wherever I go I face collapse, dark and prevailing violence everywhere» [3, p. 342] clearly stated. Shokan explained the downfall of the art and knowledge center in flourishing countries in the Middle Ages, people's darkness, refusal of art and knowledge, living with an implicit belief in the religious web.

Shokan Ualikhanov's contribution to the history of Middle Ages was recognized by scientific society while he was alive. Alkei Margulan in his surveys says about Shokan as a traveller, geoghapher, a research scientist of Central Asia and East Turkestan, his scietific works are recognized worldwide, his works were highly marked, first of all say the Russian scientists [5, p. 94].

\section{Main part}

Shokan Ualikhanov's scientific and teaching work was improved at the end of the $50 \mathrm{~s}$ and at the beginning of the $60^{\mathrm{s}}$ of the XIX century. Shokan's literary heritage is a result of a few travels and journeys of the scientist to Kazakhstan and Cetral Asia. Shokan came here fo the first time in 1855, here the young scientist traveled around Central Kazakhstan, Zhetisu, Tarbagatay mountains. While traveling Ualikhanov established the scientific wide reseach in Kazakh people, their life, traditions and customs [5, p. 95].

The ways of studying Shokan's scientific works started to develop and flourish in 1856 . He took part in a big military scientific expedition led and organized by colonel Khomentovsckyi M.M. The aim of the expedition was to get introduced to the Kirgiz and put the boundaries of Issyk-Kul to the topographic map. In May, 1856 Shokan started his journey. His journey started from Alakol to the Central Tan-Shan and further to Issyk-Kul [6, p. 34]. In this trip trying to show Issyk-Kuil on paper, as a result the boundaries of the lake were changed on a new map.

Shokan was influenced by rare monuments of an old civilization in Zhetisu and Tan-Shan. He was particularly involved in ancient municipal culture in Issyk-Kuil, remains of sewers, landmarks, epigraphy and balbal stones. Surveys of these monuments gave a good description of Issyk-Kuil boundaries and peoples living in the whole Zhetisu in past for Shokan Ualikhanov. Shokan wrote the following about it: «Despite the prevailing nomadism in Rusian Zhongar, settled lifestyle was developed slightly, first historic data about it, the data about Chigu town are found in the Chinese history, this town may have been located on the east shore of Issyk-Kuil and it was devoted to the uisun leader by Chinese workers, roughly to say. In middle ages, especially, in the vicinity of Ili settled lifestyle was widely developed. ... In this part of Asia there were many religious congregations of nestorianism and monophysitism, and according to the Catalan map, there was a Sirian Jacobites' temple in Issyk-Kuil. Since Christianity was widely spread here, he was in exile a few times. In XVI century there were a few muslim settlements around the Issyk-Kul...» [6, pp. 35-36].

Shokan visited the Alatau Kirgiz again in 1857. Shokan Ualikhanov rewrote first the famous Kirgiz epic legend «Manas» and scientifically analyzed in relation to history and literature, translated its extract «The death and the funeral of Koketai khan» into Russian. Shokan: «The Kirgiz have a single legend called «Manas» dates from the time of Nogai. «Manas» is an encyclopedic collection of the black Kirgiz all myths, fairy-tales, stories grouped into one period and one man - hero Manas's attendants. It is like the lliada. «Manas» is the whole work of collected individual stories» [6, p. 38] concluded. Shokan liked an interesting extract «The death and the funeral of Koketai khan» from «Manas» with its truth, precious information about historic and ethnographic, household, everydaylife and law rules of Kirgiz people, on top of that the data about relationships between ancient tribes lived in Kazakhstan. In addition, in this extract there is a clear description of Kirgizs' move from South Siberia to Tan-Shan in past.

The Europe literature was completely unfamiliar with the legend «Manas» before Shokan and Radlov. Seiphuddin Akhsikenti was the first to write its short plot, lived in Fergana at the beginning of the XVI century. But Seiphuddin's notes were not widely spread afterwards in Central Asian literature and remained unknown in this period [5, p. 248]. 
Shokan was involved in the ancient history of Kirgiz people. In particular, he thought about lives of Kirgiz people in Yenisey and Tan - Shan at the same time, the Pamir and Altay mountains. It was an important scientific target for the young scientist to solve this important issue, to identify the history of move of Kirgiz people between the Sayan and Tan Shan mountains. Considering that this issue could be based on some written data, genealogy stories and legends, he was involved in archive data.

Reffering to the collected data Shokan was the first who proved that the Tan - Shan Kirgiz were the local autochthon settlements and had lived there for a long time. But in past, they were connected with the Yenissei basin, Altay and Zhongar valley and Tan - Shan as a whole geographical unit, those were the ways the Kirgiz tribes move from the south to the north.

Shokan started his scientific job while studying in a military school. Being interested in the works by orientalist Berezin I.N., he made comments on his work "Khan's orders" and it was his first scientific work. He took a lot from "Jami at tauarikh» by Kadirgaly Zhalairy, first translated his basic chapters, gave explanations, additionally made up a dictionary of oriental terms.

Shokan in his letter to Berezin I.N. gave a multi-sided explanation of the word "Kazakh". He «all my collected data prove that the Kazakh were not ancient people as Firdausi said, after Berdibek's death, as a result of a sudden internal war, tribal alliances were established". The legends about the origins of Kazakh, Shaibani -name and Zhamigat -tauarih tales prove that. A Kazakh from the tribe Zhamigat -tauarih zhalairi belonging to the Great Ulus (land) marked it» [6, p. 61] he concluded.

Shokan's deep scientific work «Kazakh genealogy» is very important for the historic research of Kazakh people in Middle Ages. Shokan did not only collect these data on his own, bright, but he supported intelligent people of the past Kazakh society. After this heritage was declared in books by Potanin. Shokan Ualikhanov in his work marked the old Kazakh tradition of dividing into tribes. He wrote about the tribes who joined the Kazakh. Shokan wrote at the time of kipchak, kanly, zhair that kanly lived on the shores of Issyk-Kul, Shu, Talas before the Mongols attacks, kipchaks lived from Ogiz time till the time of Chingizkhan for 400 years Don, between Edil and Oral, that's why they were called Deshti Kipchak.

Shokan expressed the following opinion about the establishment of Kazakh kaganate. He said: «In dark years, Kazan, the Crimea, Astrakhan khanates as a result of robbery, violence, made up first separated tribes from Golden Orda (land) and Shagatai Ulus in different places and countries ... established unions and elected a prince from Chingiskhan's descendant as a khan. A different political society was established from different independent tribes. In Sarayishik - Nogaily, Mogol Ulus (land) - in Tashkent, in Seikhun valley - the centers of Kazakh kaganates were established» [7, pp. 165-166].

Shokan Ualikhanov's article «The remains of shamanism in Kazakhstan» about the Kazakh beliefs and life it was deep knowledge. While a lot of reserchers wrote about Kazakh people, Shokan said that they were Muslims and kept traditions of shamanism. However, they did not explain the reasons of shamanism among Kazakh people and any surveys were not conducted [8, p. 52].

Shokan said that shamanism was not investigated as a religion and the released article «Black belief» by Banzarov was the only work about shamanism. Shokan said that this was the only work about shamanism and it could not be called total shamanism and this book was based on the writings of Buddha's lamas. However, in comparison with shamanism in Buddhism, shamanism in Kazakhstan was better developed, but compared with the Mongolians it was not kept better, because it was mixed with Muslim beliefs [8, p. 53] he wrote.

Shokan explained the mixture of Islam and shamanism in the following way. Islam could not be developed without mullahs' help. He said that Muslim people altered shamanism and saved themselves. For instance, ongon - spirit, the God of the Sky - Allah, or God, the spirit of land - arch foe, fairy, dius and jinn were altered [8, p. 55]. In addition, Shokan proved the mixed Kazakh nomadic customs and traditions with the traditions and customs of shamanism, explanations, still alive Kazakh tales and their importance in the survey of ancient times. Shokan explained that shamanism is paying respect to nature.

A researcher scientist of shamanism Hillary S. Webb clearly explains the signs and features of shamanism: «The shaman has a special relationship with the spirits, different from that of people who are not shamans; The shaman has a special way of interacting with the spirits, different from that of people who are not shamans. The means of contacting, visiting, or inviting the spirits include, but are not limited to, ingesting psychoactive plants and mushrooms, fasting, dreaming, drumming, dancing, and undergoing states of pain, deprivation, and isolation; The shaman interacts with these other-thanhuman persons on behalf of human persons, either individually, as clients, or as a community, or even himself; At least some of the shaman's performances are public and involve the elements of dramatic performance-props, costumes, music, movement, players, audience, plots, comedy, suspense, stagecraft, conjuring, poetry, and dialogue» [9].

Shokan Ualikhanov as a famous recongnized brave traveler made his journey to Kashgar between 1858 and 1859 . Having been introduced to the geography of an unfamiliar land to Europe, its history and political system, cultural features, he made a great contribution to the survey in East Turkestan. Shokan first provided the information about Ualikhan kozha who had cut off the head of the outstanding geographer Adolph Shlagintveit who set off for Kashar a year before. [6, $p$. 40].

In spite of the dangerous travel to Kashgar, he decided to achieve his goal. Shokan was there for half a year (from October 1, 1858 to the middle of March, 1859). During this period of time he studied Kashgar city, surveyed the land of six spheres. In past, the towns: Kashgar, Aksu, Three Turpans, Yanissar, Yarkend and Khotan surrounded in the North with the Tan-Shan mountains, in the south with Kuan -Lun were called six spheres.

Shokan met there merchants, politicians, scientists, writers from different countries, listened to their reliable data about the present and past of the Six Spheres. Also, he took some historic data, local official data and books from written data, completed from the additional tales by officials and merchants.

Shokan started his journey again on 11 March. The results of Shokan Ualikhanov's expedition to Kashgar were very important. It arose a great interest for many scientists. 
Shokan brought from Kashgar «The history of Sutuk Bugrakhan», «the History of Tuguluk temir khan», «the history of hajjis», "Abumuslim Maurizi» and othere rare oriental manuscripts, in addition, a collection of rock formations, axstone samples, herbaria, monuments in numismatics, etc. Shokan Ualikhanov's rich collection of data, included pictures of its population and their occupation drawn in pencil, is special in East Turkestan.

Shokan Ualikhanov's recognized worldwide work «Six spheres or Chinese province Nan -Lu (Small Bukharya) about the lives of six eastern towns in 1858-1859 made his name famous. It was devoted to the history and geography of all the East Turkestan peoples, social structure, scientific achievements in the time of Sh. Ualikhanov became the first scientific work. Shokan in this work gave a deep discription of the unknown before local geography, flora and fauna, six main cities, people, ethnography and history. Shokan brought large information about the history of East Turkestan. He wrote that East Turkestan history starts from the time of Khang dynasty. East Turkestan people first started their religious beliefs from Buddhism and it continued till IX century when Islam came. In accordance with the Shokan's data, it was difficult to say the time of Buddhism development, but according to the Chinese data it appeared and developed in the time of Khang dynasty. According to Shokan's survey, Islam completely took over tax payment in the XVI century in East Turkestan. Shokan wrote that XIV-XV centuries were very special for Central Asian people. Since then the hajas became very important. So two beliefs were established. The followers of Imam Kalan were called ishkiya, the followers of haja Iskhakh uali called themselves iskhakiya, then the first were called aktau, the others were called karatau, Shokan wroter [3, p. 128]. So those two controversial beliefs were spread among all habitats of Six spheres, the misunderstandings between them finally caused East Turkestan to lose independence. The reason of Zhongars possible rule was stated by Haja Appak, the head of Aktau, because the Zhongars and Chinese used the misunderstandings between the two beliefs.

Small Bukharya people did not have a common name, they called themselves acoording to the towns where they lived Kashgar, Khotan, Komull etc., or just local people. But the Chinese called them Chantu (returned heads), the Kalmik Khotan, the Central Asian people, Kirgiz and Burutt called them Kashgar [3, p. 161].

Ualikhanov's countrymen - scientists, writers and military experts highly marked Shokan Ualikhanov's surveys in Kashgar, it was considered as complete work «it is a real innovation in geography, it is very useful for the government and science», «European geographers-scientists and orientalists' gaps represented for the administration till present time» [6, p. 46].

\section{CONCLUSION}

In conclusion, Shokan explained the lag behind of the counties in Central Asia by monarchical regime and Islam. That's why Shokan criticized Islam in preventing from developing. He considered the medieval ideology as the reasons of downfall and collapse, people's graying out.

Shokan Ualikhanov being in close creative and friendly negotiations with Russian leading representatives, he appealed the people to study European and world science.

Shokan knew fantastically a great number of languages of East and West. Shokan Ualikhanov as a research scientist of the history of peoples in Central Asia reached the following scientific innovations. He was the first who rewrote the single epic legend «Manas» and scientifically analyzed it. English researchers say about «Manas» legend «In the Central Asian Republic of Kyrgyzstan, there has been resolute attempt to employ the pre-eminent national heritage icon, Manas, in this respect. Batyr-khan Manas is the principal hero of the Manas epos, an acclaimed collection of epic tales that tell of the formation, life, struggles and triumphs of the Kyrgyz people and represent the highpoint of a widespread Central Asia oral culture» [10]

The Extract of «The death and the funeral of Koketai khan» was firstly translated into Russian. Shokan was the first who brought a new way of historic data into science, Kazakh and Kirgiz oral folk traditions. As a result of the famous trip to Kashgar, he brought unknown before for science precious information about the country behind the Iron Curtains. In the article «the vestiges of shamanism in Kazakhstan» he tried to show the difference of Kazakh shamanism. While studying the history of Kirgiz people Shokan proved first that the Tan-Shan Kirgiz were local autochthon habitants who lived there from ancient times. Alkei Margulan wrote in his work «he was the first to raise ethnogenesis issues of Asian Turkic peoples, the role of Islam, social and political sytem, etc., a number of unsolved historic issues and tried to solve them» [5, p. 50].

Summarizing the abovementioned opinions, it is seen how Shokan Ualikhanov in his life made a great contribution to the reseach in the mediviual history of Central Asia.

Shokan's absorbance of his grandmother's tales from his childhood, then his father's negotiations with the top-level Russian scientists, then the knowlege taken from the society of the military school and great teachers, his negotiations with the outstanding great scientists in his short life, unique, super things left for the next generation as heritage, gave him great opportunities.

\section{ACKNOWLEDGMENTS}

We wish to thank Bolat Komekov, Akademic of the Kazakhstan Academy of Sciences. It would not have been possible to write this paper without the cooperation of the library staff Eurasian National University after L.N. Gumilev and Nazarbayev Center. We are grateful to all of them.

\section{REFERENCES}

[1] Research Methods in Education. By Louis Cohen, Lawrence Manion, Keith Morrison. This seventh edition published. 2011. by Routledge, New York. p. 248

[2] Research Methods in Anthropology: Qualitative and Quantitative Approaches. By Harvey Russell Bernard. Published by AltaMira Press. 2011. the USA, pp. 288-290 
[3] Ualikhanov, Sh. Sh. 2010. A collection of compositions in many volumes. Volume III. Almaty p. 424

[4] Alan Bryman. 2010. The Lands of the Eastern Caliphate: Mesopotamia, Persia, and Central Asia. Guy Le Strange Current edition published by Cosimo Classics, pp.8-9

[5] Compiled by Margulan, D.A., Margulan, D.A. 2011. Compositions by Margulan A.Kh. V.10. Almaty. p. 592

[6] Ualikhanov, Sh. Sh. 2010. A multi-volumed collection of compositions. Volume I. Almaty. p. 376

[7] Ualikhanov, Sh. Sh. 2010. A multi-volumed collection of compositions. Volume II. Almaty. p. 464

[8] Ualikhanov, Sh.Sh. 2010. A multi-volumed collection of compositions. Volume IV. Almaty, p. 496

[9] Expanding Western Definitions of Shamanism: A Conversation with Stephan Beyer, Stanley Krippner, and Hillary S. Webb. 2013. Anthropology of Consciousness. Volume 24, Issue 1, pp. 57-75

[10] Festivals, Tourism and Social Change: Remaking Worlds/Edited by David Picard and Mike Robinson. Printed and bound in Great Britain by the Cromwell Press. 2006. p. 172.

\section{Autobiography of the author}

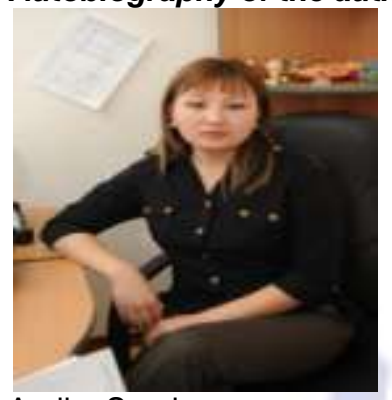

Aurika Serubaeva,

Doctorant of the Department of Eurasian research of the Eurasian National University after L.N. Gumilev. Author about 5 articles. The fields of research are the role of personality (as an example Shokan Ualikhanov).

Kazakhstan, 010000

Astana, Mirsoyan Street 20, flat 81

Tel.: +7 (7172) 28-36-67

Mob.: +7 7079985183

e-mail: serubaeva aurika@mail.ru

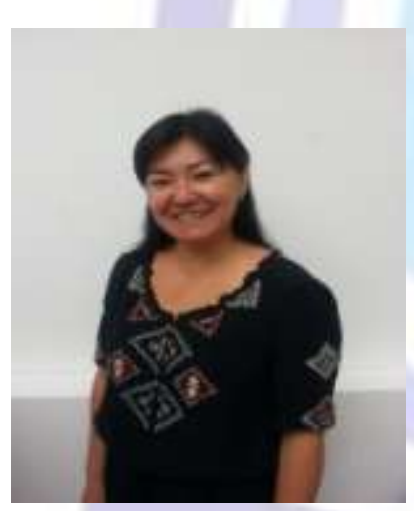

Arna Sarsambekova,

Kandidat of historical Sciences, Associate Professor of the Eurasian National University after LN Gumilev. Author of more than 20 articles, textbook. The area of research interests is Anthropology of Kazakhs of Russia.

Kazakhstan, 010000

Astana, Pobedy av. 67, Street, flat 103

Tel.: +7 (7172) 518417

Mob.: +7 7013125723

e-mail: sasz55@mail.ru 